\title{
Zarzadzanie budynkami zabytkowymi w Uniwersytecie Warszawskim
}

\section{Management of historical real estate by the Univesity of Warsaw}

\begin{abstract}
Warszawa jest miastem, w którego Śródmieściu po II wojnie światowej zachowało się niewiele obiektów zabytkowych. Uniwersytet Warszawski jako właściciel części tego dziedzictwa pełni szczególną rolę, remontując i rewitalizując zabytki. Dbałość o utrzymanie właściwego stanu technicznego i wizualnego budynków poza doraźnym charakterem posiada także wymiar przekazu historycznego o dawniejszym wyglądzie budynków oraz otoczeniu, w jakim się znajdują. Uniwersytet Warszawski posiada w swoich zasobach 45 obiektów zabytkowych, których większość zlokalizowana jest w Śródmieściu: na terenie centralnym (kampus historyczny), Powiślu i w Ogrodzie Botanicznym. W artykule podjęto próbę przedstawienia większości wykonanych, pod nadzorem konserwatora zabytków, robót budowlanych służących utrzymaniu i poprawie stanu technicznego nieruchomości zabytkowych uczelni, ale również działań na rzecz ich rewitalizacji. Analiza badawcza dotyczy związku pomiędzy wizerunkiem Uczelni a odbiorem przez interesariuszy wykonanych prac rewitalizacyjnych.
\end{abstract}

\section{Keywords}

Uniwersytet Warszawski, zabytki, remont, rewitalizacja, konserwator zabytków, interesariusze

\begin{abstract}
Warsaw is a capital city, where, after the second world war very few historical building were preserved. Care for the maintenance of the proper technical and visual condition of the buildings also has the dimension of a historical message about the former appearance of buildings and their surroundings. The University of Warsaw owns in its resources 45 historic objects, most of them located down town: in the city center (historical campus), in Powiśle district and Botanic Garden. In this paper an attempt was made to present not only the majority of construction works (made under the supervision of the conservator) maintaining and improving the technical condition of the University's historical properties, but also actions taken for their revitalization. The most interesting problem is how the image of the University will change after revitalization.
\end{abstract}

\section{Słowa kluczowe}

University of Warsaw, monuments, renovation, revitalization, conservator, interested group

JEL: A13

Str. $34-40$

\section{Bibliografia}

Bończak-Kucharczyk, E. (2018). Ustawa o gospodarce nieruchomościami, komentarz. Warszawa: Wolters Kluwer.

Bieniek, G., Kalus, S., Marmaj, Z. i Mzyk, E. (2011). Ustawa o gospodarce nieruchomościami. Warszawa: Lexis Nexsis.

Czakon, W. (2011). Podstawy metodologii badań w naukach o zarzadzaniu. Warszawa: Wolters Kluwer.

Garlicki, A. (1982). Dzieje Uniwersytetu Warszawskiego 1915-1939. Warszawa: PWN.

Gawron, H. (2010). Podstawy zarządzania nieruchomościami. Poznań: Wydawnictwo Uniwersytetu Ekonomicznego w Poznaniu.

Kisilowska, H. (2011). Nieruchomości: zagadnienia prawne. Warszawa: Lexis Nexsis.

Kotler, P. i Lee, N. (2008). Marketing w sektorze publicznym. Mapa drogowa w wyższej efektywności. Warszawa: WSPiZ im. L. Koźmińskiego.

Knorr, R. H. (1984). Public Relations als System-Umwelt-Interaktion. Wiesbaden: Dargestellt an der Öffentlichkeitsarbeit einer 
Universität.

Lewandowski, K. (2005). Zarządzanie nieruchomościami. Warszawa: Lexis Nexis.

Nalepka, A. (2006). Zarządzanie nieruchomościami: wybrane zagadnienia. Kraków: Wydawnictwo Akademii Ekonomicznej w Krakowie.

Mikołajewska, B. (2009). Zarządzanie nieruchomościami publicznymi. Warszawa: C.H. Beck.

Obłój, K. i Wąsowska, A. (2015). Studium przypadku. W: M. Kostera (red), Metody badawcze w zarządzaniu humanistycznym. Warszawa: Sedno.

Pęchorzewski, D. (2014). Gospodarowanie nieruchomościami w jednostkach sektora finansów publicznych, praktyczne wskazówki w świetle obowiqzujących przepisów i orzecznictwa. Warszawa: C.H. Beck.

Strzelczyk, R. (2014). Prawo nieruchomości. Warszawa: C.H. Beck.

Szachułowicz, J. (2001). Gospodarka nieruchomościami. Warszawa: Wydawnictwa Prawnicze PWN.

Trojanek, M. (2013). Uwarunkowania efektywnej gospodarki nieruchomościami publicznymi. Kalisz: Wydawnictwo PWSZ.

Tymiński, J. (2014). Zarządzanie nieruchomościami: aspekty ekonomiczno-techniczne. Piotrków Trybunalski: Naukowe Wydawnictwo Piotrkowskie.

Wancke, P. (2015). Prawne aspekty gospodarowania nieruchomościami w ujęciu praktycznym. Warszawa: Poltext.

Wierzbowski, B. (2014). Gospodarka nieruchomościami: podstawy prawne. Warszawa: Lexis Nexis.

Wócik, K. (2013). Public relations. Wiarygodny dialog z otoczeniem. Warszawa: Oficyna a Wolters Kluwer Business.

Yin, R. (2015). Studium przypadku w badaniach naukowych. Kraków: Wydawnictwo Uniwersytetu Jagiellońskiego.

Żróbek, R. i in. (2014), Podstawy i procedury gospodarowania publicznymi zasobami nieruchomości. Olsztyn: Wydawnictwa UWM. 